\title{
Influence of meditation on estate planning decisions: evidence from Indian survey data

\author{
Amarjit Gill ${ }^{1 *}$, Harvinder S. Mand ${ }^{2}$, John D. Obradovich ${ }^{3}$ and Neil Mathur ${ }^{4}$
}

\author{
* Correspondence: \\ gill@edwards.usask.ca; \\ agill02@shaw.ca \\ 'Edwards School of Business, The \\ University of Saskatchewan, 25 \\ Campus Drive, Saskatoon, SK \\ S7N-5A7, Canada \\ Full list of author information is \\ available at the end of the article
}

\begin{abstract}
Background: Intestate death can lead to the distribution of assets against the personal wishes of the deceased and is a problem in India, as 80\% of Indians die without making a last will. Following the concepts of decision theory (i.e., the theory of choice), stewardship theory, agency theory, and signaling theory, the purpose of this study is to examine the influence of meditation on estate planning decisions. This study also seeks to extend previous findings on the influence of religious beliefs on the estate planning decisions of Canadians to that of Indians.

Methods: Employed and self-employed individuals from India were surveyed regarding their perceptions of meditation and estate planning decisions.

Results: The survey indicates that mediation positively influences the estate planning decisions while individuals who practice meditation have greater preferences for estate planning compared with those who do not. The findings suggest that individual assets, family size, and education positively influence the estate planning decisions of Indians.

Conclusion: Reported meditation, individual assets, family size, location, education, and gender are positively correlated with the estate planning decisions of Indians.
\end{abstract}

Keywords: Meditation, Estate planning, Assets, Income, India

\section{Background}

In India, $80 \%$ of the population die without making a last will (Kohli 2004). One reason might be related to lower individual assets, because the richest 1\% of Indians own 58\% of the country's wealth (Manku 2017). Estate planning, however, is a critical aspect of wealth management in modern society because intestate death can cause distribution of assets among relatives whom the estate holder might not have liked to receive a share (Global Property Guide 2015). Madura and Gill (2016) defined estate planning as the process by which individuals determine how their wealth will be distributed before and/or after their death.

Personal wishes, such as donations for the goodwill of society to certain organizations, including children's hospitals, would likely not be addressed in the case of intestate death (Madura and Gill 2016). Many issues arise with the distribution of assets of a deceased person who died intestate in India. For example, Section 212 of the Indian Succession Act 1925 does not grant any right to any part of the property of a person who has died intestate unless letters of administration have been granted by a court of competent jurisdiction. However, Section 212 of the Indian Succession Act does not

(c) The Author(s). 2017 Open Access This article is distributed under the terms of the Creative Commons Attribution 4.0 International License (http://creativecommons.org/licenses/by/4.0/), which permits unrestricted use, distribution, and reproduction in any medium, provided you give appropriate credit to the original author(s) and the source, provide a link to the Creative Commons license, and indicate if changes were made. 
apply in the case of intestacy of a Hindu, Mohammedan, Sikh, Buddhist, Jaina, Christian, or Parsi (Mint 2012). The Hindu Succession Act 1956 applies to Hindus, Buddhists, Jains, and Sikhs (Money Life 2014). Thus, different intestate acts are applied to the death of people from different religions in India. Therefore, a valid last will is necessary.

Following the concept of decision theory (i.e., the theory of choice), this study concentrates on the relationship between meditation and the estate planning decisions of individuals. In the context of this study, meditation is considered a prayer to God. Decision theory is defined as the rationale underlying an agent's choices (i.e., an estate holder and a last will writer) in writing a last will for beneficiaries (principal) to minimize the agency problem. ${ }^{1}$ Weirich (1983) argued that a decision maker's options are usually translated into future actions. Future actions, in the context of this study, are actions related to asset distribution among beneficiaries described in the last will. Individuals have a strong impression that one of the options fits their needs better than the others do (Zander et al. 2016); therefore, they might sign power of attorney to family members who follow similar beliefs. Some decisions involve an intertemporal choice-a decision between a present alternative (i.e., power of attorney) and a potential future prospect (i.e., last will to distribute assets) (Mattson and Jackson 2015).

In general, the literature lacks a deeper understanding of the link between religion and personal financial management. Apart from ethical investing and risk aversion, meditation could also motivate certain personal financial planning behavior, such as estate planning, since meditation improves consciousness in decision-making (Nash and Newberg 2013). Estate planning is one of many financial risk management strategies. To the extent that a religious person is risk averse, he or she might be more inclined to mitigate personal risks by engaging in estate planning. Meditation comes from religious beliefs (Caponigro 2012); therefore, it can affect a wide range of decisions, as explained by Silverman (2012), from end-of-life health care and organ donation, to funeral, burial, or cremation arrangements, and to the distribution of assets among heirs and charitable bequests.

Meditation, as conscious training of attention aimed at modifying mental processes to enhance mental wellbeing (Walsh and Vaughan 1980), modulates brain activities associated with cognitive control, emotion regulation, and empathy to improve individual decision-making (Sun et al. 2015). In addition, by strengthening mental flexibility (Bauer-Wu 2010) and consciousness in decision-making (Nash and Newberg 2013), meditation influences individual decision-making styles (McNaughton 2003). In addition, meditation plays a stewardship role ${ }^{2}$ to improve individual decisions without disciplining the individual's mind and emotions to align objectives of the last will, power of attorney, beneficiaries, joint tenancy, and appointment of a trustee with the personal interests of the estate holder. Thus, meditation is among the important factors that can lead to sound estate planning decisions of individuals related to the distribution of assets among family members and society for noble causes; therefore, this study concentrates on the relationship between meditation and the estate planning decisions of individuals with the aim of answering the following research question.

Do meditation practices influence the estate planning decisions of individuals in India?

The findings of this study show that mediation positively influences the estate planning decisions of individuals in India. Although indirectly, the findings lend some support to 
those of Gill and Mathur (2017), since meditation arises from religious beliefs. Thus, this study adds substance to the existing literature on the relationship between meditation and estate planning decisions.

The structure of the rest of the paper is as follows. Section 2 examines the previous literature and develops hypotheses. Section 3 describes the data and methodology used to investigate the research question. Section 4 analyzes and discusses the empirical results. Section 5 presents the discussion and conclusion, considers the implications of the findings, and provides recommendations for future research.

\section{Literature review}

Religious factors might affect people's desire to support their families and their willingness to contribute to society and people in need. In the words of Keister (2003), "people draw on the tools they learn from religion to develop consistent strategies for dealing with problems and for making decisions such as savings, investment, and consumption decisions" (p. 178). Hence, religion affects wealth accumulation by shaping individuals' goals and by allowing them to develop a set of competencies that can enhance wealth ownership and the distribution of their wealth among family members and society.

\section{Meditation and estate planning decisions}

Many religious individuals rely on their beliefs when making various decisions, such as estate planning. Religion encourages family and social welfare (Fagan 1996). Therefore, it is important to understand the relationship between meditation and estate planning decisions by which individuals manage financial risk, such as sharing their estate with unwanted parties. Increasing research suggests an association between attending religious services and better mental health (Idler 1987; Koenig et al. 1997; Musick et al. 2004; Idler et al. 1992), which helps in making sound financial planning decisions, such as estate planning.

According to Wilson (1997, p. 1), "an understanding of religious teaching helps put ethical issues, including those involving economic relations, in a fuller perspective". Information asymmetry issues are high in India (Sriram 2005), in which the estate holder has better information than potential beneficiaries do. Religion has a strong influence on personal and social values. Previous studies show that prayer (i.e., meditation) has been used as a self-enhancing intervention for centuries and is inherently a religious activity (see Joshi et al. 2008).

The merger of meditation, decision theory (i.e., financial decision-making), stewardship, and signaling ${ }^{3}$ theory is crucial for the mitigation of agency problems in the family. Decision making is regarded as the thought processes through which a judgment or course of action is identified and selected from several alternative possibilities based on an individual's values and preferences (Rilling and Sanfey 2011). Preferences about the distribution of assets after death might cause an agency problem between the estate holder (agent) and family members and other parties who expect to share in the estate (principal) of a deceased person. Previous studies have suggested that meditation might play a role in reducing economic decision bias (Birnie et al. 2010; Leiberg et al. 2011; Klimecki et al. 2012). Prayer enhances individual mental well-being (Poloma and 
Pendleton 1991). Thus, meditation through prayer improves individual decisionmaking and reduces information asymmetry issues in the family.

McNaughton (2003) pointed out that meditation influences the decision-making styles of individuals. In the context of this study, meditation, by playing a stewardship role, encourages personal rationalization about writing a last will, signing a power of attorney, adding beneficiaries on personal savings accounts, having joint tenancy, and appointing a trustee. Stewardship involves "a duty of care and conservation with regard to property/assets" (McCuddy and Pirie 2007, p. 961); that is, transferring assets to desired parties after the death of the estate planner.

Although beneficiaries might not have all the information about the estate distribution after the death of the estate holder because of information asymmetry, the last will can send a positive signal to beneficiaries. Signaling theory addresses information asymmetries between two parties in which the sources of asymmetric information are concerned with information about quality or information about intent (Stiglitz 2000; Su et al. 2015). In the case of estate planning decisions, the last will writer has better information about the names of beneficiaries on the last will but beneficiaries might not have the same information about the intentions of the last will writer. Meditation, which comes from religious beliefs (Caponigro 2012), minimizes the agency problem between the last will writer and his or her family members by sending a positive signal to beneficiaries. The findings of Gill and Mathur (2017) suggested that level of religious beliefs positively impacts estate planning decisions of individuals.

Estate planning is critical in India, because a much of the estate can go to unwanted third parties. In addition, different Succession Acts apply to the intestate death of individuals based on their religions (see Mint 2012; Money Life 2014). Silverman (2012) argued that religious beliefs could affect a wide range of decisions, including the distribution of assets among heirs and charitable bequests. Such issues as the distribution of assets among heirs and charitable bequests can be a source of passionate disagreement within a family, especially one with varying degrees of religious devotion. Thus, dying intestate can cause unwanted issues related to the distribution of wealth among unwanted parties.

In summary, meditation practices influence estate planning decisions of individuals. Hence, this study proposes the following hypothesis.

Hypothesis 1 (H1): The estate planning decisions of individuals are positively associated with their meditation in India.

\section{Assets and estate planning decisions}

Although meditation is the main explanatory variable in this study, assets are another important factor in the estate planning decision; therefore, the relationship between assets and estate planning decisions is explored. Estate planning saves time and yields a tax-planning advantage when individuals deal with wills, gifts in trust, insurance trusts, estate and gift tax returns, gifts or purchases of stock, and family estate plans, among others (Madura and Gill 2016). Estate planning helps explore options involved in tax planning, such as the valuation of intra-family gifts of minority interests in a closely held family business context, limited liability companies, and the use of charitable techniques (Business Wire 2006). Intestate death can create more problems for 
foreigners in India, where intestate succession takes a long time for settlement. A local will made in India helps probate assets easily (Global Property Guide 2015).

Different acts apply to intestate death based on individual religions (see Mint 2012; Money Life 2014), which creates even more challenges in the distribution of assets. Potential intestate death creates and increases the chances of distribution of assets among unwanted parties whom family members might not like. For example, if a Hindu female dies intestate, assets are distributed equally among her children, husband, parents, and parents' heirs. The potential threat of distribution of assets among unwanted parties causes an agency problem between agent (parents or other parties with a last will) and principal (family members or other parties who are expecting the ownership of assets). In addition, net wealth tax is levied at $1 \%$ on a taxpayer's net assets if they exceed INR 3 million (Global Property Guide 2015). A last will minimizes agency problems between asset holder(s) and family members. Thus, greater assets can encourage individuals to make a last will in India.

Limited availability of literature indicates that greater assets can lead to greater challenges related to asset distribution among family members, relatives, and other parties. Since estate planning minimizes the abovementioned issues, a positive relationship between assets and estate planning decisions is expected. Hence, this study proposes the following hypothesis.

Hypothesis 2 (H2): Estate planning decisions of individuals are positively associated with their level of assets in India.

\section{Methods}

\section{Research design}

We utilized survey research, specifically, a non-experimental field study design, since it is a useful tool for studying sensitive opinions, attitudes, preferences, and the behavior of individuals (Gall et al. 1996).

\section{Measurement}

To remain consistent with previous research, measures pertaining to estate planning decisions were adopted from Edwards (1991). To collect raw data for constructing the variables, the survey questions were designed in a way to ensure that respondents felt comfortable to disclose information with confidentiality. For instance, rather than asking respondents to disclose actual asset holdings, five individual ranges were used. The ranges of total assets were as follows: 1) INR 0-1,000,000, 2) INR 1,000,001-2,000,000, 3) INR 2,000,001-3000,000,4) INR 3000,001-4,000,000, and 5) more than INR $4,000,001$. Note that to reduce heteroscedasticity (i.e., stabilize variance), the following variables were converted into their natural logarithmic (ln) form: individual age, family size, individual income, and individual assets.

\section{Estate planning decisions}

The definition of estate planning decisions (EPD), for the purposes of this study, is the general perception of the research participants about the extent to which they perceive that they have a proper will to distribute assets among their family members and others; power of attorney in the name of their family members who hold similar beliefs 
to the will holder; added names of beneficiaries on life insurance policies and bank accounts to ensure fair distribution of wealth; joint tenancy with the rights of survivorship; and appointed a trustee who follows similar beliefs to distribute the assets after death. Following the definition, five separate components measure the EPD index. The responses were categorized on a 5-point Likert Scale ranging from 1, representing "strongly disagree," to 5, representing "strongly agree." Responses were initially collected for each of the above five sources of EPD. The five measures are highly correlated with correlation values ranging from 0.912 to 0.962 . Therefore, a new index was constructed using principal component analysis. The EPD index was constructed using the first component, which explains approximately $94.58 \%$ of the variation. ${ }^{4}$

\section{Meditation}

Meditation $(M E D)$ is a dummy variable assigned a value of 1 if a respondent answered yes for meditation and 0 if not. Religion encourages family and social welfare (Fagan 1996) and individual meditation (Caponigro 2012). Meditation, in turn, influences the estate planning decisions of individuals; therefore, meditation was used as the main explanatory variable.

\section{Assets}

Assets of a research participant (ASSETS) is a categorical variable with an assigned value of 1 = INR 0-1,000,000, 2 = INR 1,000,001-2,000,000, 3 = INR 2,000,001-3000,000, $4=$ INR 3000,001-4,000,000, and $5=$ more than INR 4,000,001. For empirical analyses, the natural logarithm (ln) of average assets was calculated for categories one to four. To calculate the natural logarithm (ln) for category five, INR 4,000,001 was used. The assets variable was used as both an independent and a control variable. People with a higher level of assets will pay higher probate fees if they die intestate (Manulife Financial 2007) and their last wishes might not be fulfilled. Therefore, assets can be considered to motivate the estate planning decisions of individuals.

\section{Income}

Income of a research participant (INCOME) is a categorical variable with an assigned value of 1 = INR $0-100,000,2=$ INR 100,001-1,000,000, $3=$ INR 1,000,001-2,000,000, $4=$ INR 2,000,001-3000,000, and $5=$ more than INR 3000,001. For empirical analyses, the natural logarithm (ln) of average income was calculated for the first four categories. To calculate the natural logarithm (ln) for category five, INR 3000,001 was used. Income might not have a direct impact on estate planning decisions although it does have a direct impact on asset accumulation; therefore, it was used as an independent variable to calculate the fitted value of assets and as a control variable to test the relationship between religious beliefs and estate planning decisions of individuals.

\section{Marital status}

Marital status $(M S)$ is a dummy variable with an assigned value of 1 if a research participant reported he or she was married and 0 otherwise. Marital status influences estate planning decisions because married individuals might want to ensure fair distribution of assets among their children. Therefore, marital status might impact the estate planning decisions of an individual. This might not be the situation for single people unless they have children. 
Age

Age $(A G E)$ is measured as the actual age of a research participant. For the empirical analyses, the natural logarithm $(\mathrm{ln})$ of the actual age of a research participant was calculated. Once people grow older, life expectancy tends to decline; therefore, age might have a positive impact on estate planning decisions.

\section{Family size}

Family size (FAMILY) is measured as the number of family members of a research participant who live together. For the empirical analyses, the natural logarithm (ln) of the number of family members of a research participant was calculated. Larger family size can lead to conflict about the distribution of assets if the asset holder dies intestate. In addition, Indian society is collectivistic and promotes social cohesion and interdependence (Chadda and Deb 2013); therefore, family size influences the estate planning decisions of individuals in India.

\section{Geographic location}

Geographic location ( $L O C A T I O N)$ is a dummy variable with an assigned value of 1 if a research participant lives in an urban area and 0 if a research participant lives in a rural area. People in cities might have better information on estate planning compared with rural areas because of better access to information sources. For example, rural areas of India have a lack of information sources, such as libraries. Therefore, location might influence the estate planning decisions of individuals.

\section{Education}

The education of a research participant (EDUCATION) is a categorical variable with an assigned value of 1 = High school or less, 2 = College diploma, 3 = Bachelor's degree, $4=$ Master's degree, and $5=\mathrm{PhD}$ degree or more. People with higher education might understand the needs of estate planning better than lower educated people; therefore, education might influence estate planning decisions.

\section{Gender}

Gender (GENDER) is a dummy variable with an assigned value of 1 if a research participant is male and 0 if female. Women tend to be more religious than men (Francis 1997) and tend to be more sensitive to the needs of family and society. Therefore, gender might influence estate planning decisions. In addition, India is a male-dominated country (Hemalatha 2014); therefore, some differences in the impact of gender on estate planning decisions should be evident.

\section{Sampling frame, questionnaire distribution, and collection}

Given that the population is "abstract" (i.e., it was not possible to obtain a list of all members of the focal population), a non-probability (purposive) sample was obtained. In a purposive sample, participants are screened for inclusion based on criteria associated with members of the focal population. To achieve a convenience sample, an extensive list of employed and self-employed individuals' names and telephone numbers was used to distribute surveys and to conduct telephone interviews. To create a list of telephone numbers and addresses, referrals from friends, relatives, family members, 
and religious places such as temples were used. In addition, telephone directories and the internet were used to collect business names, addresses and telephone numbers of research participants.

India was selected because it is believed that meditation originated on the Indian sub-continent in the ancient Vedic times (Sharma 2015); therefore, India can be considered a good site for data collection to test the relationship between meditation and estate planning decisions.

The Indian sample included Indian employed and self-employed (business owners) individuals living in Punjab, Haryana, Himachal, Maharashtra, Rajasthan, and Uttar Pradesh. The majority of surveys came from Punjab, India because of the lack of participation in research from other states. The sample included approximately 3000 research participants. A total of 845 surveys were completed over the telephone, through personal visits, or were received by e-mail, of which 10 were not usable. Thus, the response rate was roughly $28 \%$. The remaining cases were assumed to be similar to the selected research participants.

Although the information collected was self-reported and variables were largely measured objectively, common method bias was not a concern in this study. This was supported by the results of a factor analysis (Podsakoff and Organ 1986).

\section{Confidentiality}

To solve confidentiality issues, all subjects were assured that personal identification, including names, would not be disclosed during the analysis, interpretation, and publication of data. Before conducting the telephone interviews, all subjects were instructed regarding the purpose of the research, and asked for their permission to use the data provided. Any information obtained in connection with this study that could identify specific respondents is confidential and will be disclosed only with subjects' permission or as required by law.

\section{Empirical models and analysis}

\section{Empirical models}

As the literature review indicates, meditation practice (MED), which comes from religion (Caponigro 2012), and assets (ASSETS) positively affect the estate planning decisions (EPD) of individuals; therefore, MED and ASSETS were considered as the main explanatory variables to estimate the following regression models:

$$
\begin{aligned}
& E P D i=\alpha 0+\alpha 1 \cdot M E D i+\Sigma X i+\varepsilon i \\
& E P D i=\alpha 0+\alpha 1 . A S S E T S i+\Sigma X i+\varepsilon i
\end{aligned}
$$

In above Models (1) and (2), $i$ refers to a research participant, EPD is the estate planning decisions of an individual, and $X i$ represents individual control variables corresponding to research participant $i$. $\varepsilon i$ is a normally distributed disturbance term. In estimated Model (1), $\alpha 1$ measures the magnitude at which $M E D$ influences the estate planning decisions of individuals. In estimated Model (2), $\alpha 1$ measures the magnitude at which ASSETS influence the estate planning decisions of individuals. These models were extended by considering a set of the control variables. The coefficients of 
the variables of the models were estimated by applying ordinary least squares (OLS) regressions. ${ }^{5}$ Eq. (1) was used to test $\mathrm{H} 1$ and Eq. (2) was used to test $\mathrm{H} 2$.

Because of problems related to endogeneity and reverse causality between estate planning decisions, individual assets, and individual income, a two-stage least squares (2SLS) regression was used (Goss and Roberts 2011). For example, estate planning decisions could be associated with individual assets. On the other hand, individual income is likely to affect changes in individual assets and vice versa. Therefore, the assets variable is a good candidate to serve as an instrument in estate planning decisions, and income serves to predict an individual's asset level.

To implement the procedure, an instrumental variable (INCOME) was introduced in the first stage. The first stage involves regressing individual assets on individual income together with the other control variables. This regression is described in Eq. (3-1):

First-stage regression model:

$$
Z i=\beta O+\beta 1 . I N C O M E i+\Sigma X i+\varepsilon i
$$

In Eq. (3-1), $Z i$ is a continuous variable representing individual assets (ASSETS) of research participant $i$, and INCOME implies individual income associated with research participant $i$. $\beta 1$ measures the magnitude at which individual income influences the probability of ASSETS accumulation. $X i$ represents individual control variables corresponding to research participant $i . \varepsilon i$ is a normally distributed disturbance term. The coefficients of Eq. (3-1) were estimated by applying OLS regressions. ${ }^{6}$

The second stage involves regressing the estate planning decisions on the fitted value of ass $Y_{i}={ }_{0}+{ }_{1} \cdot \bar{Z}_{i}+\sum X_{i}+{ }_{i}$ ets. This regression is described in Eq. (3-2):

$$
Y_{i}=\gamma_{0}+\gamma_{1} \cdot \bar{Z}_{i}+\sum X_{i}+\varepsilon_{i}
$$

In Eq. (3-2), $Y i$ is the individual's perception of the $E P D$ whereas $\bar{Z}_{i}$ is is the predicted probability of individual assets. $X i$ represents individual control variables corresponding to research participant $i$. $\varepsilon i$ is a normally distributed disturbance term. Hence, $\gamma 1$ estimates the effect of ASSETS on the EPD driven by individual income. The coefficients of Eq. (3-2) were estimated by using the OLS method in the case of EPD. The expected probability of ASSETS obtained from (3-1) was used in (3-2).

\section{Descriptive data analysis}

In the dataset, some of the variables, except $E P D$ index, are individual dummy variables. The data show that the distribution of EPD is almost symmetrical around their mean values and thus, there is no outlier present in either of the indexes. Skewness for all the scales used in this study fell within the range of -0.590 to -0.755 , which can be considered excellent. According to Mason et al. (1991), values of skewness usually range from -3 to +3 when the data are normally distributed. Varimax rotation explains $94.58 \%$ of the variance in the original scores. The test statistic for the Kaiser-Meyer-Olkin measure of sampling adequacy is 0.89 . Kaiser (1974, p. 36) suggested that accepting values greater than 0.50 indicates the validity of factor analysis.

A question subset was analyzed to calculate the weighted factor scores. The principal component is strongly correlated with five of the original variables: EPD1, EPD2, EPD3, $E P D 4$, and EPD5. The Cronbach's alpha for EPD is 0.986 , indicating that scale items 
used for this variable are reliable. Cronbach's alpha, which normally ranges between 0 and 1 , shows the reliability coefficient of scale items. There is, however, no lower limit to the coefficient. A Cronbach's alpha coefficient closer to 1 shows greater internal consistency of the scale items (Gliem and Gliem 2003). ${ }^{7}$

A comparative mean t-test examines the differences in variables between individuals who meditate and individuals who do not. The results of the mean t-test show that individuals who meditate look more favorably on estate planning compared with individuals who do not. For example, the mean $M E D$ score for individuals who meditate is 0.08 compared to -0.63 for individuals who do not meditate. Likewise, assets and income are higher for individuals who meditate compared to individuals who do not (see Table 1).

\section{Correlation coefficient}

The correlation coefficient matrix shows that MED, ASSETS, INCOME, FAMILY, LOCATION, and EDUCATION ( $\rho M E D, E P D=0.223 ; \rho A S S E T S, E P D=0.212$; $\rho I N C O M E, E P D=0.120 ; \rho F A M I L Y, E P D=0.095 ; \rho L O C A T I O N, E P D=0.118$; and $\rho E D U C A T I O N, E P D=0.206)$ are positively and significantly correlated with $E P D$, and $M S(\rho M S, E P D=-0.069)$ is negatively and significantly correlated with $E P D$. These results imply that meditation, assets, income, family size, location, and education positively influence the estate planning decisions of individuals in India while and marital status negatively influences the estate planning decisions of individuals (see Table 2).

\section{Results}

Table 3 reports the estimated coefficients of Eqs. (1) and (2). The results show that $E P D$ is positively and significantly associated with MED, ASSETS, FAMILY, LOCATION, EDUCATION, and GENDER.

Table 1 Descriptive statistics

\begin{tabular}{|c|c|c|c|c|c|c|c|c|}
\hline & Mean & SD & Min & Med & Max & $\begin{array}{l}\text { With } \\
\text { MED }\end{array}$ & $\begin{array}{l}\text { Without } \\
\text { MED }\end{array}$ & $\begin{array}{l}\text { Compare } \\
\text { Mean T-test }\end{array}$ \\
\hline$\overline{E P D}$ & 0.00 & 1.00 & -2.32 & 0.35 & 1.25 & 0.08 & -0.63 & $0.71^{* *}$ \\
\hline EPD1) Proper will decision & 3.67 & 1.15 & 1 & 4 & 5 & 3.76 & 2.91 & $0.85^{* *}$ \\
\hline EPD2) Power of attorney & 3.59 & 1.14 & 1 & 4 & 5 & 3.67 & 2.90 & $0.77^{* *}$ \\
\hline EPD3) Beneficiary decision & 3.66 & 1.14 & 1 & 4 & 5 & 3.75 & 2.93 & $0.82^{* *}$ \\
\hline EPD4) Joint tenancy decision & 3.56 & 1.15 & 1 & 4 & 5 & 3.65 & 2.87 & $0.78^{* *}$ \\
\hline EPD5)Trustee appointment decision & 3.54 & 1.17 & 1 & 4 & 5 & 3.62 & 2.89 & $0.73^{* *}$ \\
\hline $\mathrm{RB}$ & 0.90 & 0.30 & 0 & 1 & 1 & 1.00 & 0.12 & $0.88^{* *}$ \\
\hline MED & 0.89 & 0.32 & 0 & 1 & 1 & & & \\
\hline ASSETS & 14.66 & 0.70 & 13.12 & 15.07 & 15.20 & 14.71 & 14.29 & $0.42^{* *}$ \\
\hline INCOME & 13.33 & 1.39 & 1.61 & 13.82 & 14.91 & 13.41 & 12.63 & $0.78^{* *}$ \\
\hline MS & 0.25 & 0.43 & 0 & 0 & 1 & 0.23 & 0.47 & $-0.24^{* *}$ \\
\hline AGE & 3.58 & 0.29 & 2.89 & 3.56 & 4.17 & 3.60 & 3.46 & $0.14^{* *}$ \\
\hline FAMILY & 1.48 & 0.53 & 0.00 & 1.61 & 2.71 & 1.52 & 1.24 & $0.28^{* *}$ \\
\hline LOCATION & 0.54 & 0.50 & 0 & 1 & 1 & 0.54 & 0.51 & 0.03 \\
\hline EDUCATION & 2.88 & 1.29 & 1 & 3 & 5 & 2.92 & 2.53 & $0.39^{* *}$ \\
\hline GENDER & 0.66 & 0.47 & 0 & 1 & 1 & 0.66 & 0.68 & -0.02 \\
\hline
\end{tabular}

Notes: ${ }^{*} p<0.05$ and ${ }^{* *} p<0.01$; Variables include estate planning decision (EPD), meditation (MED), assets (ASSETS), income (INCOME), marital status (MS), age (AGE), family size (FAMILY), location (LOCATION), education (EDUCATION), and gender (GENDER). Standard deviation (SD); Minimum (Min); Median (Med); Maximum (Max); and T-test (Compare Mean T-test) 


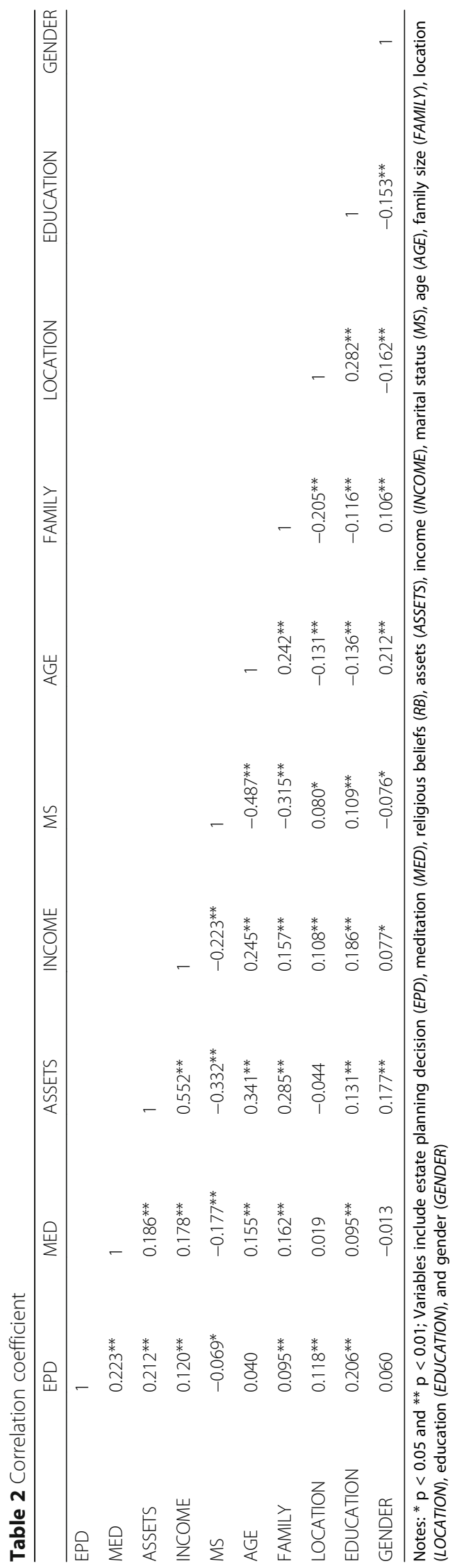


Table 3 Results from first stage regressions ${ }^{a}$

\begin{tabular}{|c|c|c|c|c|c|c|}
\hline \multicolumn{7}{|c|}{ Dependent variable $=\mathrm{EPD}$} \\
\hline Variables & $\begin{array}{l}\text { (I) } \\
\text { EPD }\end{array}$ & $\begin{array}{l}\text { (II) } \\
\text { EPD }\end{array}$ & $\begin{array}{l}\text { (III) } \\
\text { EPD }\end{array}$ & $\begin{array}{l}\text { (IV) } \\
\text { EPD }\end{array}$ & $\begin{array}{l}\text { (V) } \\
\text { EPD }\end{array}$ & $\begin{array}{l}(\mathrm{VI}) \\
\mathrm{EPD}\end{array}$ \\
\hline \multirow[t]{2}{*}{ MED } & $0.705^{* *}$ & & $0.601^{* *}$ & $0.588^{* *}$ & & $0.562^{* *}$ \\
\hline & $(6.60)$ & & $(5.61)$ & $(5.51)$ & & $(5.24)$ \\
\hline \multirow[t]{2}{*}{ ASSETS } & & $0.300^{* *}$ & $0.250^{* *}$ & $0.246^{* *}$ & $0.253^{* *}$ & $0.239^{* *}$ \\
\hline & & $(6.25)$ & $(5.20)$ & $(4.20)$ & $(4.15)$ & (3.98) \\
\hline \multirow[t]{2}{*}{ INCOME } & & & & -0.029 & -0.031 & -0.041 \\
\hline & & & & $(-1.02)$ & $(-1.07)$ & $(-1.42)$ \\
\hline \multirow[t]{2}{*}{ MS } & & & & & -0.060 & -0.025 \\
\hline & & & & & $(-0.66)$ & $(-0.28)$ \\
\hline \multirow[t]{2}{*}{ AGE } & & & & -0.095 & -0.066 & -0.111 \\
\hline & & & & $(-0.78)$ & $(-0.48)$ & $(-0.82)$ \\
\hline \multirow[t]{2}{*}{ FAMILY } & & & & & $0.155^{*}$ & $0.119+$ \\
\hline & & & & & $(2.28)$ & $(1.77)$ \\
\hline \multirow[t]{2}{*}{ LOCATION } & & & & & $0.216^{* *}$ & $0.209^{* *}$ \\
\hline & & & & & $(3.02)$ & $(2.97)$ \\
\hline \multirow[t]{2}{*}{ EDUCATION } & & & & $0.139^{* *}$ & $0.140^{* *}$ & $0.127^{* *}$ \\
\hline & & & & $(5.21)$ & $(5.01)$ & $(4.60)$ \\
\hline \multirow[t]{2}{*}{ GENDER } & & & & $0.144^{*}$ & $0.148^{*}$ & $0.165^{*}$ \\
\hline & & & & $(2.00)$ & $(2.01)$ & $(2.28)$ \\
\hline \multirow[t]{2}{*}{ Constant } & $-0.625^{* *}$ & $-4.403^{* *}$ & $-4.199 * *$ & $-3.892^{* *}$ & $-3.894^{* *}$ & $-3.820^{* *}$ \\
\hline & $(-6.22)$ & $(-6.24)$ & $(-6.05)$ & $(-5.40)$ & $(-4.71)$ & $(-4.70)$ \\
\hline N & 835 & 835 & 835 & 835 & 835 & 835 \\
\hline F Test & $43.54^{* *}$ & $39.05^{* *}$ & $35.99^{* *}$ & $17.64^{* *}$ & $10.93^{* *}$ & $13.08^{* *}$ \\
\hline Adjusted $R^{2}$ & 0.049 & 0.044 & 0.077 & 0.107 & 0.087 & 0.115 \\
\hline \multicolumn{7}{|c|}{ Robustness check on results from first stage regressions (Bootstrapping) } \\
\hline Variables & $\begin{array}{l}\text { (I) } \\
\text { EPD }\end{array}$ & $\begin{array}{l}\text { (II) } \\
\text { EPD }\end{array}$ & $\begin{array}{l}\text { (III) } \\
\text { EPD }\end{array}$ & $\begin{array}{l}\text { (IV) } \\
\text { EPD }\end{array}$ & $\begin{array}{l}\text { (V) } \\
\text { EPD }\end{array}$ & $\begin{array}{l}(\mathrm{VI}) \\
\text { EPD }\end{array}$ \\
\hline \multirow[t]{2}{*}{ MED } & $0.705^{* *}$ & & $0.601^{* *}$ & $0.588^{* *}$ & & $0.562^{* *}$ \\
\hline & $(5.24)$ & & $(4.63)$ & $(4.54)$ & & $(4.32)$ \\
\hline \multirow[t]{2}{*}{ ASSETS } & & $0.300^{* *}$ & $0.250^{* *}$ & $0.246^{* *}$ & $0.253^{* *}$ & $0.239^{* *}$ \\
\hline & & $(5.60)$ & $(4.72)$ & $(4.34)$ & $(4.14)$ & (3.98) \\
\hline \multirow[t]{2}{*}{ INCOME } & & & & -0.029 & -0.031 & -0.041 \\
\hline & & & & $(-1.03)$ & $(-1.03)$ & $(-1.43)$ \\
\hline \multirow[t]{2}{*}{ MS } & & & & & -0.060 & -0.025 \\
\hline & & & & & $(-0.65)$ & $(-0.27)$ \\
\hline \multirow[t]{2}{*}{ AGE } & & & & -0.095 & -0.066 & -0.111 \\
\hline & & & & $(-0.73)$ & $(-0.47)$ & $(-0.80)$ \\
\hline \multirow[t]{2}{*}{ FAMILY } & & & & & $0.155^{*}$ & $0.119+$ \\
\hline & & & & & $(2.32)$ & $(1.84)$ \\
\hline \multirow[t]{2}{*}{ LOCATION } & & & & & $0.216^{* *}$ & $0.209^{* *}$ \\
\hline & & & & & (3.10) & (3.05) \\
\hline \multirow[t]{2}{*}{ EDUCATION } & & & & $0.139^{* *}$ & $0.140^{* *}$ & $0.127^{* *}$ \\
\hline & & & & $(4.90)$ & (5.09) & (4.59) \\
\hline
\end{tabular}


Table 3 Results from first stage regressions ${ }^{a}$ (Continued)

\begin{tabular}{|c|c|c|c|c|c|c|}
\hline \multirow[t]{2}{*}{ GENDER } & & & & $0.144^{*}$ & $0.148^{*}$ & $0.165^{*}$ \\
\hline & & & & $(2.04)$ & $(2.06)$ & $(2.36)$ \\
\hline \multirow[t]{2}{*}{ Constant } & $-0.625^{* *}$ & $-4.403^{* *}$ & $-4.199 * *$ & $-3.892^{* *}$ & $-3.894^{* *}$ & $-3.820^{* *}$ \\
\hline & $(-4.85)$ & $(-5.57)$ & $(-5.56)$ & $(-5.43)$ & $(-4.51)$ & $(-4.46)$ \\
\hline N & 835 & 835 & 835 & 835 & 835 & 835 \\
\hline Wald $x^{2}$-test & $27.46^{* *}$ & $31.36^{* *}$ & $61.40^{* *}$ & $96.33^{* *}$ & $88.74^{* *}$ & $115.95^{* *}$ \\
\hline Adjusted $R^{2}$ & 0.048 & 0.044 & 0.077 & 0.107 & 0.087 & 0.115 \\
\hline
\end{tabular}

Notes: $\uparrow p<0.10,{ }^{*} \mathrm{p}<0.05$, and ${ }^{* *} \mathrm{p}<0.01$; Dependent variable includes estate planning decision (EPD). Independent variables include meditation (MED), assets (ASSETS), income (INCOME), marital status (MS), age (AGE), family size (FAMILY), location (LOCATION), education (EDUCATION), and gender (GENDER)

${ }^{\mathrm{a}}$ The lowest tolerance is 0.591 and the highest Variance Inflation Factor (VIF) is 1.692 indicating that multicollinearity is not a serious issue

The coefficients of $M E D$ in columns (I), (III), (IV), and (VI) of EPD are positive and significant at the $1 \%$ level, implying that meditation positively influences the estate planning decisions of Indians. Thus, H1 is supported. Similarly, the coefficients of ASSETS in columns (II) and (IV) of EPD are positive and significant at the $1 \%$ level, indicating that individual assets positively impact the estate planning decisions of Indians. Thus, $\mathrm{H} 2$ is supported (see Table 3).

Regardless of individual model specifications, the results consistently show that reported meditation and individual assets positively influence the estate planning decisions of Indians.

Table 4 reports the estimated coefficients of Eqs. (3-1) and (3-2). The findings show that ASSETS is positively and significantly associated with INCOME, AGE, FAMILY, EDUCATION, and GENDER, and is negatively and significantly associated with MS. In addition, the results show that $E P D$ is positively and significantly associated with ASSETS_fit, FAMILY, LOCATION, EDUCATION, and GENDER.

The coefficients of INCOME in columns (I)-(III) of ASSETS are positive and significant at the $1 \%$ level, implying that individual income positively impacts individual assets in India. The coefficient of ASSETS_fit in column (I) of EPD is positive and significant at the $1 \%$ level, suggesting that fitted value of assets positively influences the estate planning decisions of individuals in India.

The Durbin-Wu-Hausman (DWH) test was used to test for endogeneity. Regardless of the model specifications of EPD in Table 4, the DWH F-stats are significant, which shows that there are some endogeneity and causality issues between estate planning decisions, individual assets, and individual income. This study used a 2SLS regression to reduce these endogeneity issues. Bootstrapping was also used to check the robustness of the results. The bootstrapping results reveal robustness (see Tables 3 and 4).

\section{Discussion and conclusion}

The overall results suggest that the estate planning decisions of Indians are positively associated with their reported meditation. The findings also suggest that individuals who meditate look more favorably on estate planning compared with individuals who do not meditate. Assets, family size, location, education, and gender positively influence the estate planning decisions of Indians. The findings of this study lend some support to the views of Silverman (2012) and Gill and Mathur (2017) in that religious beliefs can affect estate planning decisions. 
Table 4 Results of second stage regressions and robustness check ${ }^{a}$

\begin{tabular}{|c|c|c|c|c|c|c|}
\hline \multicolumn{7}{|c|}{ Dependent variables $=$ ASSETS and EPD } \\
\hline Variables & $\begin{array}{l}\text { (I) } \\
\text { ASSETS }\end{array}$ & $\begin{array}{l}\text { (II) } \\
\text { ASSETS }\end{array}$ & $\begin{array}{l}\text { (III) } \\
\text { ASSETS }\end{array}$ & $\begin{array}{l}\text { (I) } \\
\text { EPD }\end{array}$ & $\begin{array}{l}\text { (II) } \\
\text { EPD }\end{array}$ & $\begin{array}{l}\text { (III) } \\
\text { EPD }\end{array}$ \\
\hline \multirow[t]{2}{*}{ ASSETS_fit } & & & & $0.308^{* *}$ & 0.171 & 0.115 \\
\hline & & & & $(3.49)$ & $(1.63)$ & $(1.00)$ \\
\hline \multirow[t]{2}{*}{ INCOME } & $0.280^{* *}$ & $0.245^{* *}$ & $0.226^{* *}$ & & & \\
\hline & $(19.11)$ & $(16.46)$ & $(15.37)$ & & & \\
\hline \multirow[t]{2}{*}{ MS } & & & $-0.213^{* *}$ & & & -0.089 \\
\hline & & & $(-4.15)$ & & & $(-0.92)$ \\
\hline \multirow[t]{2}{*}{ AGE } & & $0.494^{* *}$ & $0.295^{* *}$ & & 0.063 & -0.025 \\
\hline & & $(6.96)$ & $(3.84)$ & & $(0.43)$ & $(-0.17)$ \\
\hline \multirow[t]{2}{*}{ FAMILY } & & & $0.180^{* *}$ & & & $0.180^{*}$ \\
\hline & & & $(4.69)$ & & & $(2.46)$ \\
\hline \multirow[t]{2}{*}{ LOCATION } & & $-0.117^{* *}$ & $-0.079^{*}$ & & $0.176^{*}$ & $0.205^{* *}$ \\
\hline & & $(-2.86)$ & $(-1.96)$ & & $(2.47)$ & $(2.86)$ \\
\hline \multirow[t]{2}{*}{ EDUCATION } & & $0.059^{* *}$ & $0.069^{* *}$ & & $0.139 * *$ & $0.150^{* *}$ \\
\hline & & $(3.64)$ & $(4.38)$ & & $(4.66)$ & $(4.88)$ \\
\hline \multirow[t]{2}{*}{ GENDER } & & $0.148^{* *}$ & $0.153^{* *}$ & & $0.161^{*}$ & $0.169^{*}$ \\
\hline & & $(3.47)$ & (3.68) & & $(2.10)$ & $(2.20)$ \\
\hline \multirow[t]{2}{*}{ Constant } & $10.935^{* *}$ & $9.428^{* *}$ & $10.125^{* *}$ & $-4.519^{* *}$ & $-3.340^{*}$ & $-2.497 \dagger$ \\
\hline & (55.78) & (33.97) & (32.39) & $(-3.48)$ & $(-2.63)$ & $(-1.68)$ \\
\hline N & 835 & 835 & 835 & 835 & 835 & 835 \\
\hline F Test & $365.32^{* *}$ & $98.27^{* *}$ & $81.39^{* *}$ & $12.15^{* *}$ & $11.14^{* *}$ & $9.84^{* *}$ \\
\hline Adjusted $R^{2}$ & 0.304 & 0.368 & 0.403 & 0.013 & 0.057 & 0.069 \\
\hline DWH F-stat & & & & $26.13^{* *}$ & $23.34^{* *}$ & $17.20^{* *}$ \\
\hline
\end{tabular}

Robustness check on results from second stage regressions (Bootstrapping)

\begin{tabular}{|c|c|c|c|c|c|c|}
\hline Variables & $\begin{array}{l}\text { (I) } \\
\text { ASSETS }\end{array}$ & $\begin{array}{l}\text { (II) } \\
\text { ASSETS }\end{array}$ & $\begin{array}{l}\text { (III) } \\
\text { ASSETS }\end{array}$ & $\begin{array}{l}\text { (I) } \\
\text { EPD }\end{array}$ & $\begin{array}{l}\text { (II) } \\
\text { EPD }\end{array}$ & $\begin{array}{l}\text { (III) } \\
\text { EPD }\end{array}$ \\
\hline \multirow[t]{2}{*}{ ASSETS_fit } & & & & $0.308^{* *}$ & 0.171 & 0.115 \\
\hline & & & & $(2.72)$ & $(1.49)$ & $(0.87)$ \\
\hline \multirow[t]{2}{*}{ INCOME } & $0.280^{* *}$ & $0.245^{* *}$ & $0.226^{* *}$ & & & \\
\hline & (8.74) & (7.53) & (7.04) & & & \\
\hline \multirow[t]{2}{*}{ MS } & & & $-0.213^{* *}$ & & & -0.089 \\
\hline & & & $(-3.53)$ & & & $(-0.91)$ \\
\hline \multirow[t]{2}{*}{ AGE } & & $0.494^{* *}$ & $0.295^{* *}$ & & 0.063 & -0.025 \\
\hline & & $(6.92)$ & $(4.03)$ & & $(0.41)$ & $(-0.17)$ \\
\hline \multirow[t]{2}{*}{ FAMILY } & & & $0.180^{* *}$ & & & $0.180^{*}$ \\
\hline & & & (4.30) & & & $(2.46)$ \\
\hline \multirow[t]{2}{*}{ LOCATION } & & $-0.117^{* *}$ & $-0.079^{*}$ & & $0.176^{*}$ & $0.205^{* *}$ \\
\hline & & $(-2.88)$ & $(-1.99)$ & & $(2.51)$ & $(3.02)$ \\
\hline \multirow[t]{2}{*}{ EDUCATION } & & $0.059^{* *}$ & $0.069^{* *}$ & & $0.139^{* *}$ & $0.150^{* *}$ \\
\hline & & (3.32) & (3.93) & & $(4.49)$ & $(4.64)$ \\
\hline \multirow[t]{2}{*}{ GENDER } & & $0.148^{* *}$ & $0.153^{* *}$ & & $0.161^{*}$ & $0.169^{*}$ \\
\hline & & (3.29) & (3.42) & & $(2.17)$ & $(2.19)$ \\
\hline \multirow[t]{2}{*}{ Constant } & $10.935^{* *}$ & $9.428^{* *}$ & $10.125^{* *}$ & $-4.519^{* *}$ & $-3.340^{*}$ & $-2.497 \dagger$ \\
\hline & $(25.11)$ & (24.39) & (23.12) & $(-2.71)$ & $(-2.39)$ & $(-1.46)$ \\
\hline
\end{tabular}


Table 4 Results of second stage regressions and robustness check ${ }^{a}$ (Continued)

\begin{tabular}{lllllll}
\hline$N$ & 835 & 835 & 835 & 835 & 835 & 835 \\
Wald $x^{2}$-test & $76.33^{* *}$ & $289.01^{* *}$ & $422.47^{* *}$ & $7.40^{* *}$ & $48.71^{* *}$ & $64.87^{* *}$ \\
Adjusted $R^{2}$ & 0.304 & 0.368 & 0.403 & 0.013 & 0.057 & 0.069 \\
DWH F-stat & & & & $25.80^{* *}$ & $24.07^{* *}$ & $15.29^{* *}$ \\
\hline
\end{tabular}

Notes: $\dagger \mathrm{p}<0.10{ }^{*} \mathrm{p}<0.05$, and ${ }^{* *} \mathrm{p}<0.01$; Dependent variable includes assets (ASSETS) and estate planning decision (EPD). Independent variables include meditation (MED), fitted value of assets (ASSETS_fit), income (INCOME), marital status $(M S)$, age (AGE), family size (FAMILY), location (LOCATION), education (EDUCATION), and gender (GENDER)

${ }^{a}$ The lowest tolerance is 0.415 and the highest Variance Inflation Factor (VIF) is 2.412 indicating that multicollinearity is not a serious issue

While income, age, family size, education, and gender positively influence level of assets of individuals, marital status and location negatively influence the level of assets. This might be because assets are divided among family members after marriage. In addition, the level of assets might differ between urban and rural areas.

In conclusion, reported meditation, individual assets, family size, location, education, and gender are positively correlated with the estate planning decisions of Indians. Meditation minimizes the agency problem in families by minimizing asymmetric information issues and by sending a positive signal to family members about the last will to distribute assets after death. The findings show that reported meditation not only helps individuals make sound estate planning decisions but also helps increasing their income and building assets (see Table 1). Since meditation plays a stewardship role, helps build assets, and minimizes the agency problem in families, it is strongly recommended as a method of practice. Estate planning is important for fulfilling an individual's wishes upon death and minimizing asset transfer problems in India.

\section{Managerial implications}

This study has the following managerial implications. First, individuals who report high meditation practices are more likely to have a heightened desire for estate planning. The impact of meditation might not be the same on each individual because the level of beliefs differs between individuals. Therefore, one financial planning policy for all religious people might not be appropriate. Second, individuals with greater assets are more likely to have a heightened desire for estate planning.

\section{Limitations and future research}

As individuals' asset levels differ, the findings of this study should be used with caution. This study is limited to self-reported perceptions and judgments by respondents using a determined format and question survey tools. The respondents were unable to provide additional input, because a survey questionnaire was used to collect data.

The findings may only apply to individuals who are similar to those included in this research. They may not be generalizable, and therefore, should be treated with caution. Although the results show a positive correlation between meditation and estate planning decisions, there is not necessarily a causal relationship between the two.

A mail/drop-off survey data collection method contributed to a low response rate or response error. Some favorable techniques, such as the inclusion of postage-paid mail, sending a cover letter, providing a deadline for returning the survey, and promising anonymity, could be applied in the future to increase the response rate. 
The research was limited to parts of India; therefore, the generalizability of the results and the implications of this study require further research of both a quantitative and qualitative nature, conducted not only among other Indian regions and demographics but also in other countries. Future studies can improve the methodological focus and framework by collecting data from a larger number of individuals, and by including among the investigated variables other qualifying elements, such as individual spirituality (i.e., one's personal pursuit of the divine).

\section{Endnotes}

${ }^{1}$ An agency problem is an important part of the agency theory developed by Jensen and Meckling (1976).

${ }^{2}$ Donaldson and Davis (1991) developed the stewardship theory, by which the role of a steward is to advise and support people in decision-making rather than disciplining them.

${ }^{3}$ Spence (1973) pioneered signaling theory.

${ }^{4}$ The eigenvalues of the five principal components are 4.729, 0.140, 0.055, 0.042, and 0.033 , and the corresponding variances are $94.580 \%, 2.799 \%, 1.109 \%, 0.848 \%$, and $0.663 \%$, respectively. As a result, EPD index is constructed using the first component. Factors that have eigenvalues greater than one are included in the construction of the component (Kaiser 1960).

${ }^{5}$ The dependent variable $(E P D)$ is a continuous variable; therefore, the OLS regression method is used.

${ }^{6}$ The dependent variable (ASSETS) is a continuous variable; therefore, the OLS regression method is used.

${ }^{7}$ George and Mallery (2003, p. 231) provided the following rules of thumb for Cronbach's alpha values: $>0.90$ excellent, $>0.80$ good, $>0.70$ acceptable, $>0.60$ questionable, $>0.50$ poor, and $<0.50$ unacceptable.

Funding

The authors did not receive any research funding from any agency or organization.

\section{Authors' contributions}

In terms of authors' contributions, JDO drafted the manuscript; AG designed the study and performed the statistical analysis; HSM collected data; and NM helped to draft the manuscript. All authors read and approved the final manuscript.

Competing interests

The authors do not have any competing interests in the manuscript.

\section{Author details}

${ }^{1}$ Edwards School of Business, The University of Saskatchewan, 25 Campus Drive, Saskatoon, SK S7N-5A7, Canada. ${ }^{2}$ University College Benra (Dhuri), District Sangrur, East Punjab, India. ${ }^{3}$ Liberty University, 1971 University Blvd, Lynchburg, VA 24502, USA. ${ }^{4}$ College of Management and Technology, Walden University, 100 Washington Avenue South, Minneapolis, MN 55401, USA.

Received: 3 October 2017 Accepted: 1 November 2017

Published online: 11 November 2017

References

Bauer-Wu S (2010) Mindfulness meditation. Oncology 24:36-40

Birnie K, Speca M, Carlson LE (2010) Exploring self-compassion and empathy in the context of mindfulness-based stress reduction (MBSR). Stress Health 26:359-371

Business Wire (2006) Estate planning saves you time and helps you gain a tax-planning advantage when you deal with wills, gifts in trust, insurance trusts and more. Available via http://search.proquest.com.cyber.usask.ca/docview/ 445237195?rfr_id=info\%3Axri\%2Fsid\%3Aprimo. Accessed 10 June 2017

Caponigro JP 2012 All religions practice forms of meditation. Available via http://www.johnpaulcaponigro.com/blog/ 9419/all-religions-practice-forms-of-meditation-meditation-is-a-universal-practice/. Accessed 10 Jan 2017

Chadda RK, Deb KS (2013) Indian family systems, collectivistic society and psychotherapy. Indian J of Psyc 55:S299-S309 
Donaldson L, Davis JH (1991) Stewardship theory or agency theory: CEO governance and shareholder returns. Australian J of Mgmt 16:49-65

Edwards KP (1991) Planning for family asset transfers. Fin Counseling and Plan 2:55-78

Fagan PF (1996) Why religion matters: the impact of religious practice on social stability. Available via http://www. heritage.org/civil-society/report/why-religion-matters-the-impact-religious-practice-social-stability. Accessed 16 Jan 2017)

Francis $L$ (1997) The psychology of gender differences in religion: a review of empirical research. Religion 27:81-96 Gall M, Borg W, Gall J (1996) Educational research: an introduction, 6th edn. Longman Publishing, White Plains George D, Mallery P (2003) SPSS for windows: a simple guide and reference. 11.0 update, 4th edn. Allyn \& Bacon, Boston

Gill A, Mathur N (2017) Influence of religious beliefs on estate planning decision: evidence from Canadian survey data. International J of Beh Acc and Fin 6:155-167

Gliem JA, Gliem RR (2003) Calculating, interpreting, and reporting Cronbach's alpha reliability coefficient for Likert-type scales. 2003 Midwest res to practice con in adult, continuing, and com Edu. Available via https://scholarworks.iupui. edu/bitstream/handle/1805/344/Gliem\%20\&\%20Gliem.pdf?s.. (Accessed 23 Dec 2016)

Global Property Guide 2015 Inheritance tax and law. Available via http://www.globalpropertyguide.com/Asia/India/ Inheritance (Accessed 18 Jan 2017)

Goss A, Roberts GS (2011) The impact of corporate social responsibility on the cost of bank loans. J of Banking and Fin 35:1794-1810

Hemalatha P (2014) Position of women in India. Global J for Res Analysis 3:474-482

Idler E, Stanislav V, Kasl V (1992) Religion, disability, depression, and timing of death. American J of Soc 97:1052-1079

Idler EL (1987) Religious involvement and the health of the elderly: some hypotheses and an initial test. Social Forces 66:226-238

Jensen M, Meckling W (1976) Theory of the firm: managerial behavior, agency costs and ownership structure. J of Fin Eco 3:305-360

Joshi S, Kumari S, Jain M (2008) Religious belief and its relation to psychological well-being. J of the Indian Aca of Applied Psy 34:345-354

Kaiser H (1960) The application of electronic computers to factor analysis. Edu and Psy Measurement 20:141-151

Kaiser H (1974) An index of factorial simplicity. Psy 39:31-36

Keister LA (2003) Religion and wealth: the role of religious affiliation and participation in early adult asset accumulation. Soc Forces 82:175-207 Available via http://search.proquest.com/docview/229906628?accountid=36783. Accessed 15 May 152016

Klimecki OM, Leiberg S, Lamm C, Singer T (2012) Functional neural plasticity and associated changes in positive affect after compassion training. Cerebral Cor 23:1552-1561

Koenig HG, Hays JC, George LK, Blazer DG, Larson D, Landerman LR (1997) Modeling the cross-sectional relationships between religion, physical health, social support, and depressive symptoms. American J of Geriatric Psy 5:131-144

Kohli N 2004 Avoid disputes, write a will. The Times of India. Available via http://timesofindia.indiatimes.com/Avoiddisputes-write-a-Will/articleshow/802650.cms Accessed 10 Jan 2017

Leiberg S, Klimecki O, Singer T (2011) Short-term compassion training increases prosocial behavior in a newly developed prosocial game. PLoS One 6:1-10

Madura J, Gill H (2016) Personal finance, third Canadian Edition. Pearson Publishing, Toronto

Manku M (2017) Richest 1\% Indians own 58\% of country's wealth, says Oxfam report. Oxfam report Available via http:// www.livemint.com/Politics/E3n5ANHQL1ywMOdNxm6igK/Indias-1-superrich-own-58-of-the-countrys-total-wealth. html (Accessed 22 Mar 2017)

Manulife Financial (2007) Probate fees: valuing the assets of the estate. Available via https:/www1.manulife.com/can/ affinity/affinity.nsf/lookupfiles/downloadablefileic_probate2/\$file/probate2.pdf (Accessed 15 Jan 2017)

Mason RD, Lind DA, Marchal WG (1991) Statistics: an introduction, 3rd edn Harcourt Brace Jovanovich, Inc, California.

Mattson RE, Jackson MD (2015) Now or later? Attentional processing and intertemporal choice. J of Beh Dec Making 29:206-217

McCuddy MK, Pirie WL (2007) Spirituality, stewardship, and financial decision-making: toward a theory of intertemporal stewardship. Managerial Fin 33:957-969

McNaughton RD (2003) The use of meditation and intuition in decision-making: reports from executive meditators. ProQuest Information and Learning Company, Ann Arbor

Mint 2012 What happens if there is no will. HT Syndication. Available via https://search-proquest-com.cyber.usask.ca/ docview/445237195?ff_id=info\%3Axri\%2Fsid\%3Aprimo. Accessed 15 Jan 2017

Money Life 2014 Will, probate and use of trust for specific beneficiaries. Athena Info Sol Private Ltd. Available via http:// go.galegroup.com.cyber.usask.ca/ps/i.do?\&id=GALE|A364684536\&v=2.1\&u=usaskmain\&it=r\&p=ITOF\&sw=w. Accessed 15 Jan 2017)

Musick MA, House JS, Williams DR (2004) Attendance at religious services and mortality in a national sample. J of Health and Soc Beh 45:198-213

Nash JD, Newberg A (2013) Toward a unifying taxonomy and definition for meditation. Frontiers in Psy 4:806-818

Podsakoff P, Organ D (1986) Self-reports in organizational research: problems and prospects. J of Mgmt 12:531-544

Poloma M, Pendleton BF (1991) The effects of prayer and prayer experience on measures of general well-being. J of Psy and Theo 19:71-83

Rilling JK, Sanfey AG (2011) The neuroscience of social decision-making. Annual Rev of Psy 62:23-48

Sharma H (2015) Meditation: process and effects. An Inter Q J of Res in Ayurveda 36:233-237

Silverman RE (2012) Joining church and estate: passing on your religious beliefs to heirs can be a tricky business. Wall Street J. Available via http://www.ws.com/articles/SB10001424052702303816504577305704088356054. Accessed 2 Dec 2016

Spence M (1973) Job market signaling. Q J of Eco 87:355-374

Sriram MS (2005) Information asymmetry and trust: a framework for studying microfinance in India. Vikalpa 30:77-85

Stiglitz JE (2000) The contributions of the economics of information to twentieth century economics. Q J of Eco 115:1441-1478 
Su W, Peng MW, Tan W, Cheung YL (2015) The signaling effect of corporate social responsibility in emerging economies. J of Bus Ethics 134:479-491

Sun S, Yao Z, Wei J, Yu R (2015) Calm and smart? A selective review of meditation effects on decision making. Frontiers in Psy 6:1-6 Available via http://www.ncbi.nlm.nih.gov/pmc/articles/PMC4513203/. Accessed 7 Dec 2016

Walsh R, Vaughan F (eds) (1980) Beyond ego. JP Tarcher, Los Angeles

Weirich P (1983) A decision maker's options. Philos Stud 44:175-186

Wilson R (1997) Economics, ethics and religion: Jewish, Christian and Muslim economic thought. New York University Press, New York

Zander T, Cruz AL, Winkelmann MP, Volz KG (2016) Scrutinizing the emotional nature of intuitive coherence judgments. J of Beh Dec Making Available via http://onlinelibrary.wiley.com/doi/10.1002/bdm.1982/full. Accessed 20 January 2017

Submit your manuscript to a SpringerOpen ${ }^{\circ}$ journal and benefit from:

- Convenient online submission

- Rigorous peer review

- Open access: articles freely available online

High visibility within the field

- Retaining the copyright to your article

Submit your next manuscript at $>$ springeropen.com 